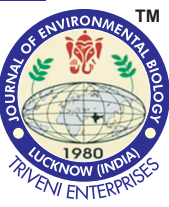

\title{
Hydro-chemistry of groundwater in a North Indian city and its suitability assessment for drinking and irrigation purposes
}

\begin{tabular}{llll}
\hline Paper received: 08.02.2018 & Revised received: 20.04.2018 & Re-revised received: 12.05 .2018 & Accepted: 23.05 .2018
\end{tabular}

\begin{abstract}
Authors Info
K. Ravindra* , Suman Mor, A. Singh ${ }^{3}$, V.J. Singh N. Dhanda ${ }^{3}$, P. Rani ${ }^{3}$ and S. Mor ${ }^{4}$ ${ }^{1}$ School of Public Health, Department of Community Medicine, Post Graduate Institute of Medical Education and Research, Chandigarh-160 012, India ${ }^{2}$ Department of Environment Studies, Panjab University, Chandigarh-160 014, India

${ }^{3}$ Department of Energy and Environmental Science, Chaudhary Devi Lal University, Sirsa-125 055, India

${ }^{4}$ Centre for Public Health, Panjab University, Chandigarh-160 025, India

*Corresponding Author Email : khaiwal@yahoo.com
\end{abstract}

\section{Edited by \\ Professor R. K. Somashekar}

Reviewed by

Dr. R. B. Raizada

Dr. P. Lakshmanaperumalsamy

\section{Abstract}

Aim : The current study aimed to identify the hydro-geological processes that control the groundwater chemistry. Further, groundwater quality was also evaluated for drinking and irrigation purposes.

Methodology : Groundwater samples were collected from a semi-arid region of North India i.e., Ellenabad, Sirsa, Haryana. The samples were analyzed following the American Public Health Association standard methods for the examination of water and wastewater.

Results : Most of the groundwater samples of study area fall under hard category. The saline nature of groundwater can be attributed to high concentration of total dissolved salts $\left(340 \pm 104 \mathrm{mgl}^{-1}\right)$. Majority of the groundwater samples showed fluoride concentration below the permissible limit of WHO and BIS $\left(1.0 \mathrm{mgl}^{-1}\right)$. Multivariate analysis including sodium absorption ratio was calculated to assess the water quality for irrigation purpose and it was found appropriate for majority of crops, except for sensitive plant species.

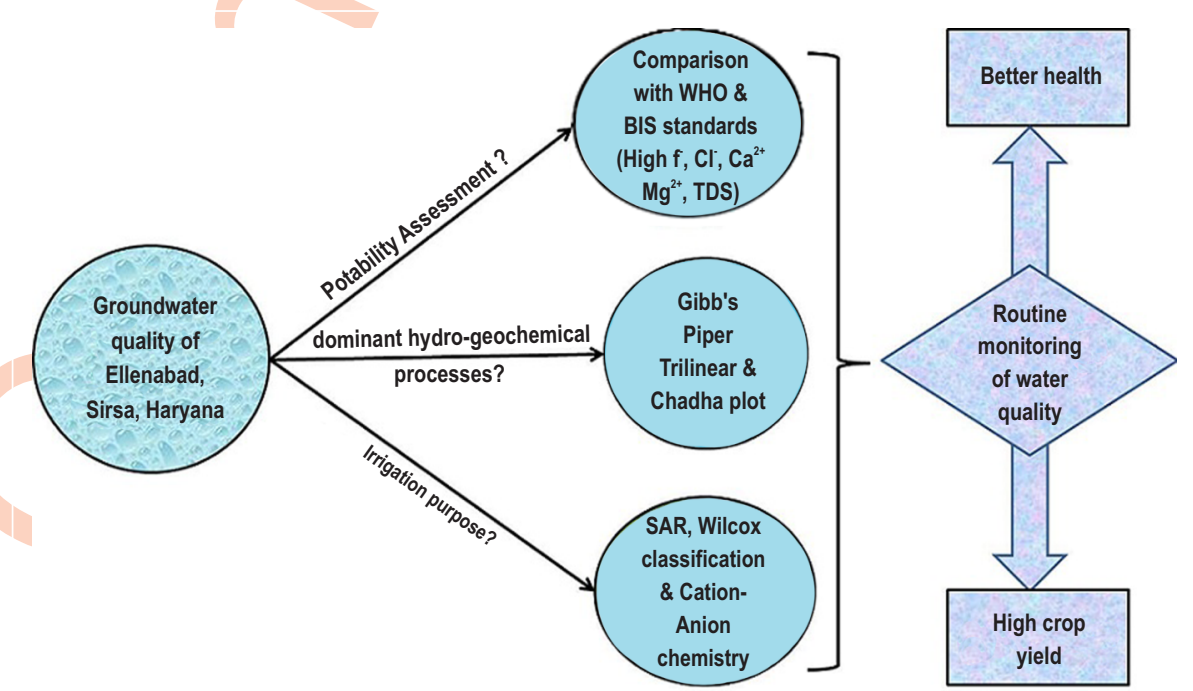

Interpretation : Potability assessment of groundwater showed that more than $40 \%$ samples were unacceptable for drinking purpose without any prior treatment, hence, it is essential to conduct a routine monitoring of groundwater to determine its aptness for drinking, domestic and agriculture purposes.

Key words: Gibb's plot, Groundwater quality, Hydro-geochemistry, Piper trilinear plot, Wilcox diagram

How to cite: Khaiwal, R., Suman Mor, A. Singh, V.J. Singh, N. Dhanda, P. Rani and S. Mor: Hydro-chemistry of groundwater in a North Indian City and its suitability assessment for drinking and irrigation purposes. J. Environ. Biol., 40, 200-210 (2019). 


\section{Introduction}

Water is one of the abundantly available substances in nature, however, to provide safe drinking water for the rural and urban population still remains a global challenge. The United Nations Sustainable Development Goals aims to provide equitable access to safe and affordable drinking water for all by 2030 (UN SDG, 2015). However, the use of water resources in power, growth of cities, intensified agriculture and industries exert greater qualitative and quantitative impacts on the hydrogeological regime of inland waters (Kulkarni et al., 2015; Mor et al., 2016, 2018; Ravindra et al., 2003). Study of hydrochemistry of groundwater is based on information regarding the groundwater chemistry which determines the suitability of water for various purposes. Hydrochemical analyses includes all major cations, anions, fluoride, ammonia, nitrate etc. Apart from these, there are many factors such as geology of area, types of rocks, chemical weathering etc. that govern the groundwater chemistry. Therefore, in order to assess groundwater quality, it is important to obtain the information regarding these factors and their interactions. Further integration of the hydrogeologic and hydrochemical data of the groundwater helps in determining the mechanisms that contro the groundwater quality of any specified area (Negi et al., 2018).

Groundwater is a prime source of domestic needs including drinking and other ecological purposes in both urban and rural India (Sabal and Khan, 2008; Babu et al., 2015; Rao et al., 2012). However, it is only valuable, when the quality is suitable for the purpose it is being explored. It caters essentially to the household needs, extensively used in industries and for irrigation (Garg et al., 2004, 2009; Kulshrestha and Sharma, 2006). These anthropogenic activities and increasing demand for better living standards exhibit immense pressure on groundwater quality (Kumar et al., 2016; Bishnoi and Arora, 2007) and hence, it is becoming contaminated with hazardous substances (Mor et al., 2006, 2013; Sharma et al., 2013). The major problem with groundwater is that once contaminated, it is very difficult to restore it. Hence, it is important to regularly monitor the water quality to protect deterioration of water resources. Routine monitoring of groundwater also reduces public health risks by ensuring safe drinking water quality and recommending timely remedial actions (Ravindra and Garg, 2006, 2007; Yadav et al., 2014). Thus, the present study aimed to evaluate the physicochemical characteristic of ground water samples in Ellenabad, Sirsa, Haryana to illustrate its suitability for drinking and agricultural purposes.

\section{Materials and Methods}

Sampling location and collection of groundwater samples : Ellenabad is located in Sirsa district of Haryana state. The city has semi-arid climate and the mean daily maximum temperature during summer ranges from $41^{\circ} \mathrm{C}$ to $46^{\circ} \mathrm{C}$. The terrain of the district is mainly $(65 \%)$ dominated by Haryana plain of flat to rolling terrain, alluvial clayed flat bed of Ghaggar river but at some places also have sand dunes of $9 \mathrm{~m}$ height. The groundwater is the main source of drinking (including municipal water supply), domestic and other ecological purpose in Ellenabad and it is being drawn out using hand pumps and tube wells.

As detailed in Table 1, total 28 sites (26 hand pumps and 02 tube wells) were selected for groundwater analysis after an initial survey of the city (Fig. 1). The survey helped to identify the hand pumps/tube wells installed at public places. These sites were selected on the basis of their frequent use by public and working of the hand pump/tubewell at the time of sampling following the WHO guidelines (WHO, 2006). Groundwater samples were collected in clean plastic bottles from hand pumps or tube wells after flushing the standing water in casting pipes and having stabilized electrical conductivity (EC) and $\mathrm{pH}$. Groundwater samples were directly transferred to the laboratory, where they were stored in the refrigerator below $4^{\circ} \mathrm{C}$ to limit the chemical alteration in groundwater.

Analytical methodology : The physico-chemical parameter of groundwater samples were examined following the APHA (2005) guidelines and all standard precautions were strictly adhered to avoid any error during analysis. The $\mathrm{pH}, \mathrm{EC}$ and temperature of groundwater were determined immediately at the sampling site. The EC values were used to calculate the total dissolved solids (TDS) as explained by Richard (1954). Quantitative chemical analysis of total alkalinity $(\mathrm{TA})$, total hardness $(\mathrm{TH})$ including cation [magnesium $\left(\mathrm{Mg}^{2+}\right)$, calcium $\left(\mathrm{Ca}^{2+}\right)$ ] and anions [chloride $(\mathrm{Cl})$, carbonate $\left(\mathrm{CO}_{3}^{2-}\right)$, bicarbonate $\left.\left(\mathrm{HCO}_{3}^{-}\right)\right]$were conducted using titration methods. Potassium $\left(\mathrm{K}^{+}\right)$and Sodium $\left(\mathrm{Na}^{+}\right)$in groundwater sample were analyzed using microcontroller based Flame Photometer (make Systronic-128). The concentration of sulfate $\left(\mathrm{SO}_{4}^{2-}\right)$ and fluoride $\left(\mathrm{F}^{-}\right)$was estimated by SPADNS method using Perkin-Elmer GmbH (lambda-2) UVIVIS spectrophotometer. The analysis was carried out in triplicate which showed reproducible results within $\pm 3 \%$ of error limit. Statistical and multivariate analysis of the data was performed using IBM SPSS-20.0.

\section{Results and Discussion}

The $\mathrm{pH}$ value of analyzed groundwater samples varied from 7.2 to 9.2. This shows that the groundwater of Ellenabad was alkaline in nature. Similar findings were reported by Bhat et al. (2016) from Gohana Block of Sonipat district where they reported $\mathrm{pH}$ in range of 7.2-9.7. The EC of the collected samples ranged from 0.2 to $12.0 \mathrm{mSm}^{-1}$, whereas the level of TDS in groundwater of Ellenabad ranged from $128 \mathrm{mg} \mathrm{l}^{-1}$ to $7680 \mathrm{mg} \mathrm{l}^{-1}$. Another study from Ellenabad reported that $\mathrm{EC}$ and $\mathrm{pH}$ varied from 0.3 - $8.7 \mathrm{dS}$ $\mathrm{m}^{-1}$ and $7.2-9.0$, respectively (Mukarukunda et al., 2016). Similar range of $\mathrm{pH}$ and $\mathrm{EC}\left(7.4-8.8\right.$ and 0.55-13.2 $\left.\mu \mathrm{mho} \mathrm{cm}^{-1}\right)$ was reported from Rewari in Haryana by Haritash et al. (2008). All groundwater samples in Ellenabad had $\mathrm{pH}$ value well within the permissible limit, except at one location i.e., Devi Lal Chowk. .

As per Bureau of Indian Standards (2012) and World Health Organization (2006), the acceptable range of TDS for 
drinking water is 300 and $500 \mathrm{mgl}^{-1}$ (Table 2) and in comparison to that, except one, all samples exceeded the BIS limit for drinking purpose, whereas 17 groundwater samples exceeded the WHO limit. It is well-known that hardness of groundwater is largely contributed by $\mathrm{HCO}_{3}^{-}, \mathrm{CO}_{3}^{2-}, \mathrm{SO}_{4}^{2-}$ and $\mathrm{Cl}^{-}$of $\mathrm{Ca}^{2+}$ and $\mathrm{Mg}^{2+}$ ions (Mor et al., 2009; Thapliyal et al., 2011). It appears from the data that hardness in Ellenabad was mainly due to $\mathrm{Ca}^{2+}$ and $\mathrm{Mg}^{2+}$ ions. The acceptable limit of total hardness as per BIS and WHO is $300 \mathrm{mg} \mathrm{l}^{-1}$. As depicted in Table 2, the hardness of groundwater sample in Ellenabad varied from $17 \mathrm{mg} \mathrm{l}^{-1}$ to $1912 \mathrm{mg} \mathrm{l}^{-1}$. TDS and $\mathrm{Cl}^{-}$ion concentration in Jhajjar district from same state were found in the range of 74.6-3920 $\mathrm{mg} \mathrm{l}^{-1}$ and 6-2439 $\mathrm{mg} \mathrm{l}^{-1}$, respectively (Gupta and Misra, 2016). This shows that the water quality in Ellenabad was comparatively better but still does not comply with the BIS standards. Further, out of 28 samples, 15 groundwater samples exceeded the BIS and WHO acceptable limit of drinking water.

The highest hardness was observed in the groundwater sample collected from a hand pump of Nimla village, which may be due to the fact that it extracts water from the shallow aquifer. Compared with BIS standard for drinking water, all the water samples had $\mathrm{HCO}_{3}{ }^{-}$above the permissible limit whereas $\mathrm{CO}_{3}^{-}$ion concentration was within the permissible limit. In $36 \%$ groundwater samples, $\mathrm{Cl}^{-}$ion level exceeded the BIS standards for drinking water. Mor et al. (2009) reported that $\mathrm{Ca}^{2+}$ and $\mathrm{Mg}^{2+}$ are common cations existing in groundwater of semi-arid location of India. Dissolved $\mathrm{Ca}^{2+}$ ions in the groundwater arises due to slow dissolution of calcium containing mineral e.g., carbonate rocks/ lime stones and it may also leach from the soils. Sheikh et al. (2017) reported that high concentration of $\mathrm{Ca}^{2+}$ and $\mathrm{Mg}^{2+}$ in groundwater of Sonipat district could be attributed to halite, anhydrite and gypsum minerals.

Similarly, Chitrakshi and Haritash (2018) also reported the presence of calcite and Kaolinite minerals in the groundwater of Haryana. In Ellenabad, $\mathrm{Ca}^{2+}$ ion concentration dominates in the groundwater than $\mathrm{Mg}^{2+}$ concentration. As shown in Table 2, $\mathrm{Ca}^{2+}$ level in groundwater varied from $11 \mathrm{mg} \mathrm{l}^{-1}$ to $482 \mathrm{mg} \mathrm{l}^{-1}$ whereas $\mathrm{Mg}^{2+}$ level ranged from $8 \mathrm{mg} \mathrm{l}^{-1}$ to $173 \mathrm{mg} \mathrm{l}^{-1}$. The BIS acceptable limits of $\mathrm{Ca}^{2+}$ was $75 \mathrm{mg} \mathrm{l}^{-1}$ in drinking water whereas in case of $\mathrm{Mg}^{2+}$ it was $30 \mathrm{mg} \mathrm{I}^{-1}$. In comparison to these limits only six samples passed the criteria for $\mathrm{Mg}^{2+}$ whereas seven samples exceeded the $\mathrm{Ca}^{2+}$ limit in drinking water. Mor et al. (2009) highlighted that in humans, $\mathrm{Ca}^{2+}$ and $\mathrm{Mg}^{2+}$ ions play an important role in nutrient requirement as they are constituent of bones. Further, $\mathrm{Ca}^{2+}$ ions play a structural role in plant cell wall, but higher concentration of $\mathrm{Ca}^{2+}$ ions in soils restrict plant growth.

As per $\mathrm{BIS}, 50 \mathrm{mg} \mathrm{l}^{-1}$ is the permissible limit for $\mathrm{Na}^{+}$ions in potable water. The $\mathrm{Na}^{+}$content in groundwater samples of Ellenabad rang from $5 \mathrm{mg} \mathrm{l}^{-1}$ to $111 \mathrm{mg} \mathrm{l}^{-1}$. Out of 28 samples, only 2 samples exceeded the $\mathrm{Na}^{+}$level beyond the permissible limit in Ellenabad. Higher concentration of $\mathrm{Na}^{+}$in groundwater may affect the taste of drinking water whereas if it is used for irrigation, it might cause salinity. The concentration of $\mathrm{K}^{+}$ranged from $3 \mathrm{mg} \mathrm{I}^{-1}$
Table 1 : Groundwater sampling locations of Ellenabad,Sirsa, Haryana

\begin{tabular}{llll}
\hline $\begin{array}{l}\text { Sampling } \\
\text { locations }\end{array}$ & HP/TW* & $\begin{array}{l}\text { Approx. } \\
\text { depth (Feet) }\end{array}$ & $\begin{array}{l}\text { Age } \\
\text { (Year) }\end{array}$ \\
\hline Bus Stand & H.P. & 90 & 12 \\
AnajMandi & H.P. & 70 & 10 \\
Nohar Road & H.P. & NA & NA \\
Janta Girls College & H.P. & 50 & 10 \\
Nohar Road/ Factory Area & H.P. & 40 & 0.4 \\
Village Mithanpura & H.P. & 50 & 6 \\
SherawaliDhani & H.P. & 50 & 10 \\
Village Kashi Ram Vas & H.P. & 65 & 1 \\
Village Nimla & H.P. & 65 & 20 \\
Village Dholpalia & H.P. & 30 & 30 \\
BehrwalaKhurd & H.P. & 20 & 1 \\
TalwaraKhurd & H.P. & 70 & 15 \\
Moji Ki Dhani & H.P. & 48 & 0.4 \\
Jivan Nagar Road & H.P. & 25 & 12 \\
Devi LalChowk & H.P. & 50 & 10 \\
Girls Govt. School & H.P. & 80 & 30 \\
Ward No. 11 & T.W. & 150 & 3 \\
Railway Station & H.P. & 70 & 5 \\
Mameran Road & H.P. & 40 & 3 \\
LakkarMandi & H.P. & 60 & 2 \\
Petrol Pump, Sirsa Road & H.P. & 70 & 6 \\
Surera Bus Stand & H.P. & 50 & 30 \\
Poharka & H.P. & 35 & 25 \\
MehnaKhera (Bus Stand) & H.P. & 40 & 20 \\
MehnaKhera (Near Canal Bank) & H.P. & 30 & 30 \\
Water Works & T.W. & 100 & 10 \\
Medpura & H.P. & 50 & 10 \\
Police Choki & H.P. & 75 & 30 \\
\hline
\end{tabular}

${ }^{*} \mathrm{HP}=$ Hand Pump, $\mathrm{TW}=$ TubeWell, NA = Not available

to $44 \mathrm{mg} \mathrm{l}^{-1}$ in groundwater, but the observed levels were well below the drinking water standards. In Ellenabad, among the major analyzed cations, $\mathrm{Mg}^{2+}$ ion dominated the groundwater samples followed by $\mathrm{Ca}^{2+}, \mathrm{Na}^{+}$and $\mathrm{K}^{+}$. Mor et al. (2009) mentioned that $\mathrm{K}^{+}$is a key player in several metabolism intermediary biological pathways. Gupta and Misra (2018) also reported water related health risks in Haryana due to high concentration of dissolved salts.

The alkalinity in groundwater is mainly derived from the dissolution of $\mathrm{CO}_{3}^{2-}$ and $\mathrm{HCO}_{3}^{-}$ions. The $\mathrm{BIS}$ has set an acceptable limit of $200 \mathrm{mg} \mathrm{l}^{-1}$ for total alkalinity in drinking water with a maximum permissible limit of $600 \mathrm{mg} \mathrm{l}^{-1}$. The total alkalinity of analyzed groundwater samples in Ellenabad varied from $268 \mathrm{mg} \mathrm{l}^{-1}$ to $1280 \mathrm{mg}$ $I^{-1}$ and only 5 samples exceeded this standard limit. Further, the levels of $\mathrm{HCO}_{3}^{-}$and $\mathrm{CO}_{3}^{2-}$ in groundwater are normally found in relation to the concentration of $\mathrm{Ca}^{2+}$ and $\mathrm{Mg}^{2+}$. The $\mathrm{BIS}$ acceptable limit of $\mathrm{HCO}_{3}^{-}$ and $\mathrm{CO}_{3}^{2-}$ in groundwater is $30 \mathrm{mg} \mathrm{l}^{-1}$ and $75 \mathrm{mg} \mathrm{l}^{-1}$. The $\mathrm{CO}_{3}^{2-}$ level in Ellenabad water samples ranges from $0 \mathrm{mg} \mathrm{I}^{-1}$ to $82 \mathrm{mg} \mathrm{l}^{-1}$ whereas the level of $\mathrm{HCO}_{3}^{-}$ions were found between $254 \mathrm{mg} \mathrm{l}^{-1}$ to $1218 \mathrm{mgl}^{-1}$. The $\mathrm{CO}_{3}{ }^{2-}$ ions were found above the BIS acceptable limit only in one sample of wood market (Lakkar Mandi). Concentration of 


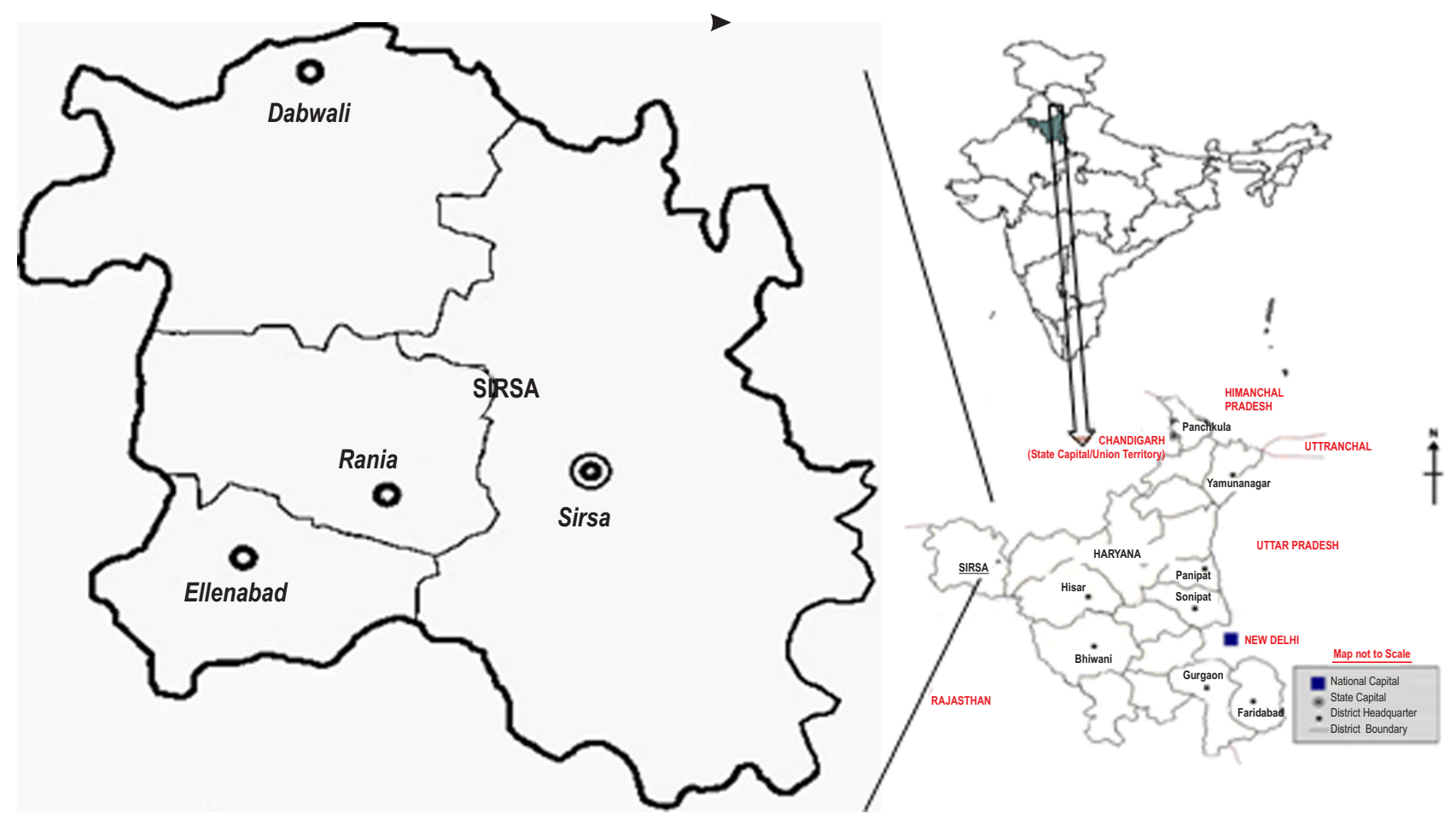

Fig. 1 : Groundwater sampling locations in Ellenabad, Sirsa, Haryana and nearby areas (see Table 2 for detail on individual samples).

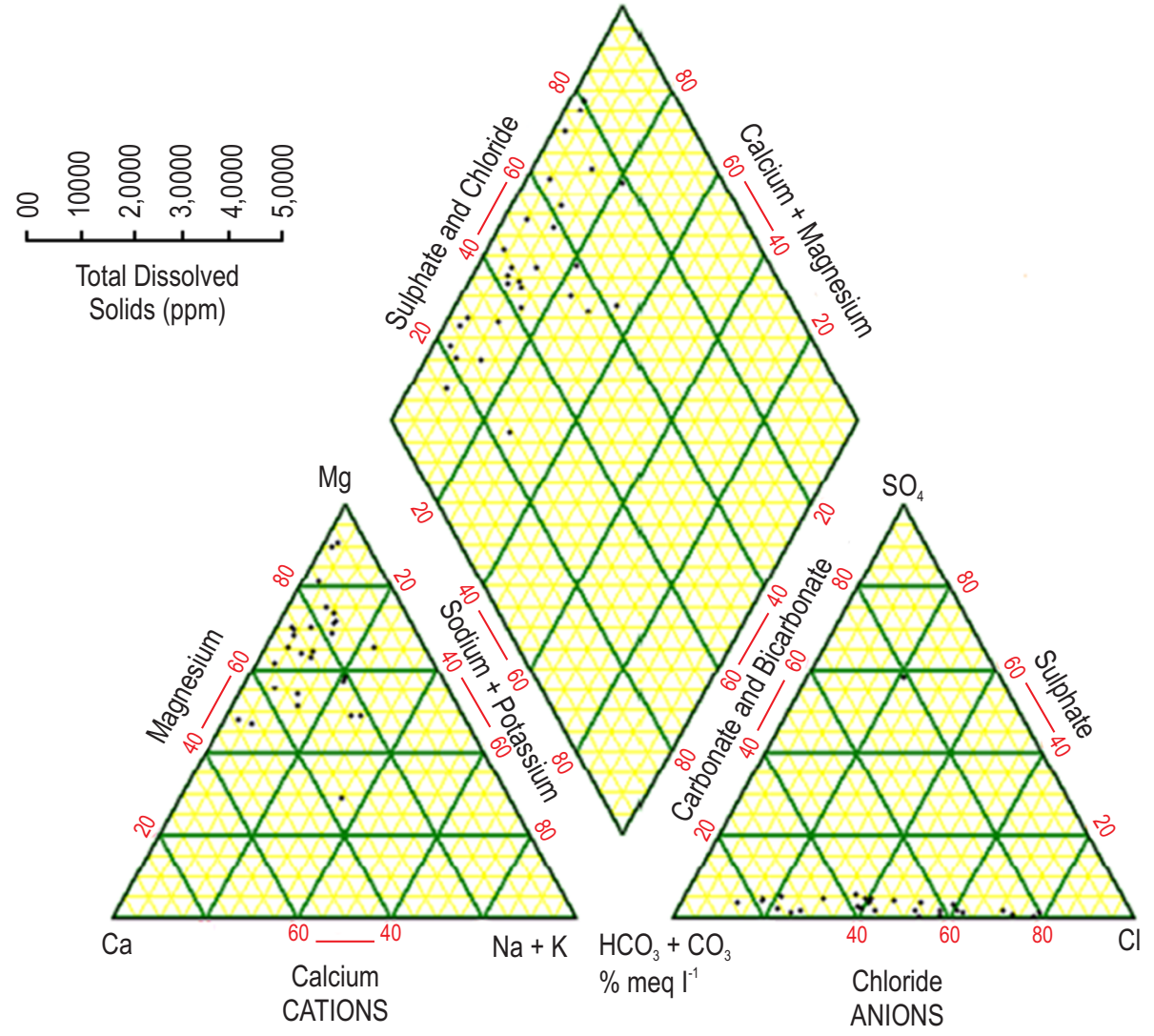

Fig. 2 : Piper trilinear plot indicating the possible group of groundwater sample collected from Ellenabad, Sirsa, Haryana. 

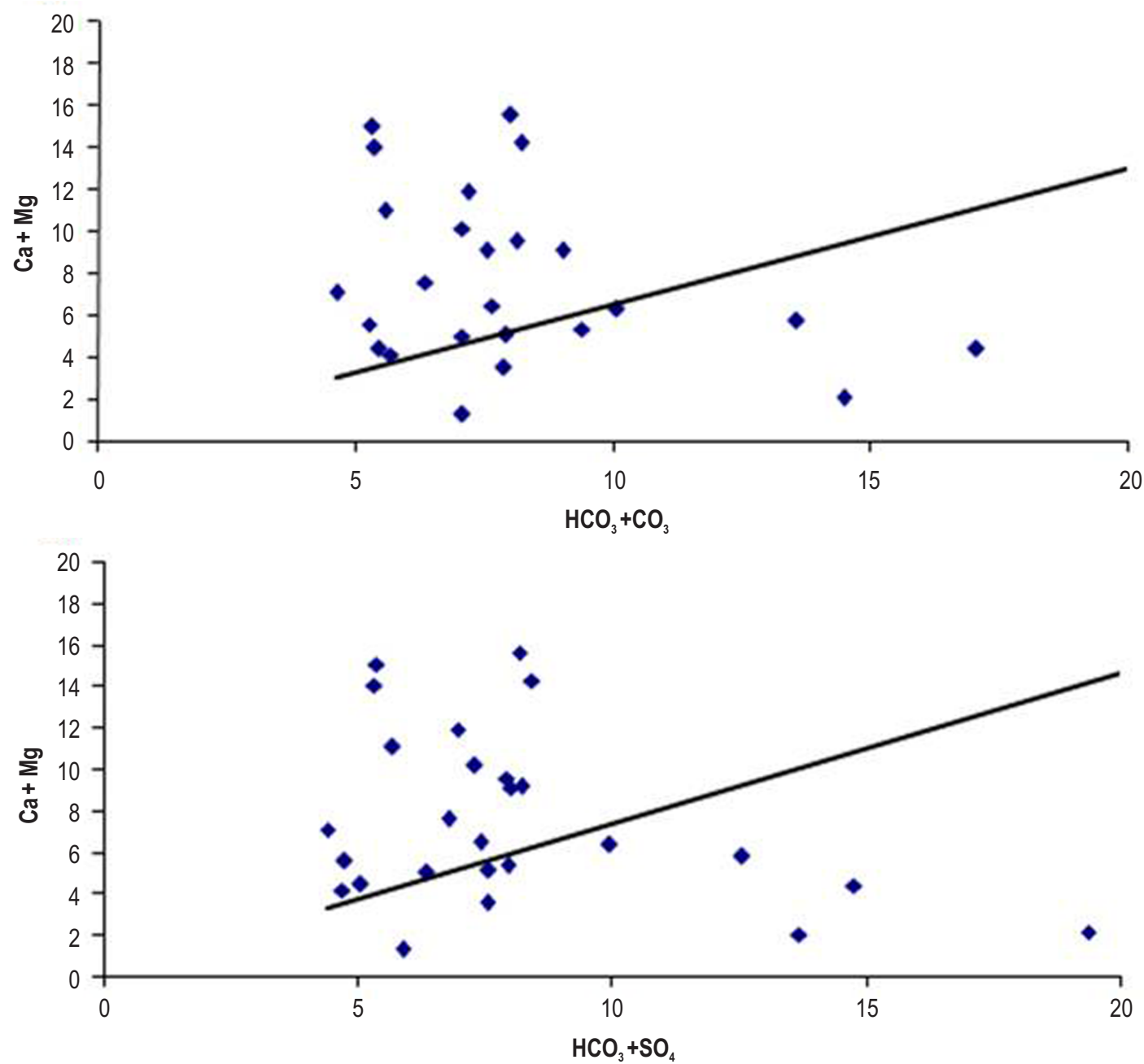

Fig. 3 : Graphs of $(\mathrm{Ca}+\mathrm{Mg})$ vs. alkalinity, $(\mathrm{Ca}+\mathrm{Mg})$ vs. acidic anion $\left(\mathrm{HCO}_{3}+\mathrm{SO}_{4}\right)$. [Values are expressed in equivalents per million (epm). The trend line represents an ideal situation where the charge balance is $100 \%$ or the error percentage in the calculation is nil].

$\mathrm{HCO}_{3}^{-}$, at all the locations in Ellenabad exceed the BIS acceptable levels including WHO limits for drinking water quality.

The maximum permissible limit for $\mathrm{Cl}^{-}$ions in potable water as per BIS is $250 \mathrm{mg} \mathrm{l}^{-1}$. The concentration of $\mathrm{Cl}^{-}$ions in groundwater ranged from $28 \mathrm{mg} \mathrm{l}^{-1}$ to $571 \mathrm{mg} \mathrm{l}^{-1}$, depicting that 10 groundwater samples had high level of $\mathrm{Cl}^{-}$ions than BIS permissible limit. The highest $\mathrm{Cl}^{-}$level was recorded near a Girls College in Ellenabad. The $\mathrm{Cl}^{-}$in groundwater seems to be of natural origin i.e, due to weathering or leaching of sedimentary rocks but contribution from the anthropogenic sources can not be ignored. $\mathrm{SO}_{4}^{2-}$ ions in groundwater originates from weathering of sulfide bearing deposits (Kaushik et al., 2002; Kumar et al., 2006; Mor et al., 2009). The $\mathrm{SO}_{4}{ }^{2-}$ ions in groundwater of Ellenabad differed from $3 \mathrm{mg} \mathrm{I}^{-1}$ to $30 \mathrm{mg} \mathrm{I}^{-1}$. Acceptable limit of $\mathrm{SO}_{4}{ }^{2-}$ as per $\mathrm{BIS}$ in groundwater is $200 \mathrm{mg} \mathrm{l}^{-1}$, and all the groundwater samples were found below this limit.
The $\mathrm{F}^{-}$level were found between $0.01 \mathrm{mgl}^{-1}$ to $0.90 \mathrm{mg} \mathrm{l}^{-1}$ in groundwater samples of Ellenabad. $\mathrm{F}^{-}$ion concentration in groundwater samples did not exceed the permissible limit (BIS, $\left.1 \mathrm{mg} \mathrm{l}^{-1}\right)$, however, lower level of $\mathrm{F}^{-}$demand public health intervention as low $\mathrm{F}^{-}$content $\left(>0.8 \mathrm{mg} \mathrm{l}^{-1}\right)$ may cause dental caries. Ravindra and Garg (2007) suggested maintaining fluoride level in drinking water ranging from 0.8 to $1.0 \mathrm{mg} \mathrm{l}^{-1}$ to avoid any public health risks. Further, Singh and Garg (2012) and Yadav et al. (2009) reported higher fluoride levels in Faridabad and Jhajjar in comparison to Ellenabad. Hence, mixing groundwater of high and low fluoride aquifer provides an alternative to minimize fluoride associated health risks. Interestingly, $\mathrm{F}^{-}$level were observed below the permissible limit in groundwater of Ellenabad. In another study by Gupta and Misra (2016), more than $60 \%$ of groundwater samples were above permissible limits for $\mathrm{F}^{-}, \mathrm{Cl}^{-}$and TDS from Jhajjar district in Haryana. Recently, Haritash et al. (2018) also reported higher levels of $\mathrm{F}^{-}$ranging from 0.5-2.4 $\mathrm{mg} \mathrm{l}^{-1}$ in Hisar, Haryana in most 


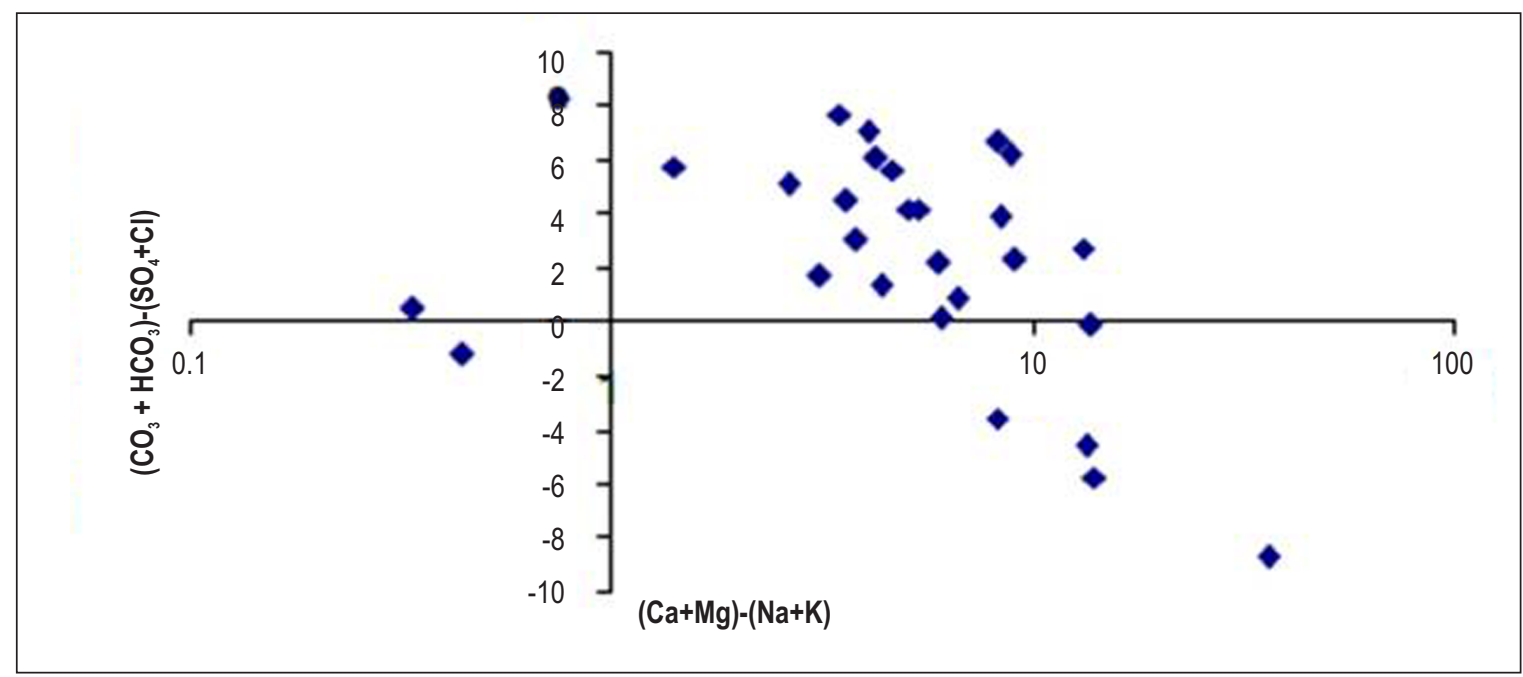

Fig. 4 : Hydro-geochemical evaluation of groundwater in Ellenabad.

of the samples. The study links high concentration of $\mathrm{F}^{-}$with the presence of easily soluble minerals such as fluorspar $\left(\mathrm{CaF}_{2}\right)$, fluorapatite $\left(\mathrm{Ca}_{5}\left(\mathrm{PO}_{4}\right)_{3}\right.$ and cryolite $\left(\mathrm{Na}_{3} \mathrm{AlF}_{6}\right)$.

Groundwater quality of Ellenabad was also assessed for drinking purpose using classification proposed by Sawyer and McCarty (1967) and Durfor and Becker (1964) (Table 3). Based on TDS concentration, 11 groundwater samples were found unsuitable for drinking purpose. Most of the groundwater samples were hard in nature. In Ellenabad, among the major analyzed cations $\mathrm{Mg}^{2+}$ ion dominates the groundwater samples followed by $\mathrm{Ca}^{2+}, \mathrm{Na}^{+}$and $\mathrm{K}^{+}$and may contribute to the hardness of water. Further, 11 samples were found brackish, indicating saline nature of groundwater. However, Singh et al. (2006a) studied the performance of irrigation system and suggested that if seepage losses could be reduced below $30 \%$ of total canal inflow, including reallocation of canal water inflow can help to decrease the salinity in Sirsa region.

Piper trilinear plot is one of the most practical graphs to compare the result of major ions in groundwater (Shankar et al., 2011; Babiker and Mohammed, 2015). Shankar et al. (2011) also mentioned that positively charged ions, shown as percent of total cations in meq $\mathrm{I}^{-1}$, were grouped in left triangle whereas negatively charged ions were grouped in right triangle. These left and right triangle were then projected into upper diamond shaped region corresponding to the upper limits of the central area. This single point intersect uniquely represents the ionic distribution of the groundwater (Madhavi and Rao, 2003). The Piper plot easily depicts the resemblance and dissimilarities in various groundwater samples, because water sample with similar quality can be grouped together (Shankar et al., 2011; Sharma et al., 2013). This also helps to identify the mixture of two source water. Based on the Piper trilinear analysis (Fig. 2), it could be inferred that groundwater in Ellenabad positioned in the zone of $\mathrm{Mg}^{2+}$ type for cations, $\mathrm{HCO}_{3}^{-}-\mathrm{Cl}^{-}$type for anions and $\mathrm{Mg}^{2+}-\mathrm{HCO}_{3}^{-}$and $\mathrm{Ca}^{2+}$ -
$\mathrm{Cl}^{-}$for mixed hydro-chemical facies. Chitrakshi and Haritash (2018) classified groundwater as $\mathrm{Na}-\mathrm{Cl}$ or $\mathrm{Ca}-\mathrm{Mg}-\mathrm{Cl}$ type in Mahendragarh region of Haryana.

Plot of $\mathrm{Ca}^{2+}+\mathrm{Mg}^{2+}$ vs. $\mathrm{HCO}_{3}^{-}+\mathrm{CO}_{3}^{2-}$ and $\mathrm{Ca}^{2+}+\mathrm{Mg}^{2+}$ vs.

$\mathrm{HCO}_{3}^{-}+\mathrm{SO}_{4}$ depicted in Fig. 3, showed the presence of excess $\mathrm{Ca}^{2+}$ and $\mathrm{Mg}^{2+}$ ions. Further, it could also be inferred that alkalinity of the groundwater may be in equilibrium due the presence of alkaline earth metals in the groundwater aquifer of Ellenabad. Analysis of groundwater samples based on Chadha diagram (Chadha, 1999; Jebreen et al., 2018) also suggests that most of the samples fall in the category of alkaline earths and weak acidic anions (Fig. 4), hence groundwater may indicate temporary hardness.

As highlighted by Jalali (2007) based on Gibbs (1970) observation that drawing a plot of TDS with respect to the weight ratio of $\mathrm{Na}^{+} /\left(\mathrm{Na}^{+}+\mathrm{Ca}^{2+}\right)$ could be helpful to extract the information on the major natural mechanism, which controls the groundwater chemistry in the region i.e., evaporation/ precipitation, rock weathering and atmospheric precipitation. As depicted in Fig. 5, Gibbs plots of the Ellenabad data signified that rock weathering and evaporation phenomena dominate the groundwater chemistry of that area. The evaporation significantly increases the concentration of ions formed due to chemical weathering, which in turn results in higher salinity levels in groundwater. Singh et al. (2006b) reported large variation in net groundwater recharge and mentioned that salt build-up over different canal commands may also affect the sustainability of irrigated agriculture in the region. Anthropogenic activities (e.g. deforestation, construction) are also responsible for the increased rate of evaporation, which in turn leads to higher levels of $\mathrm{Na}^{+}$and $\mathrm{Cl}^{-}$, and thus TDS. Ellenabad falls in an environmental region that can be better described as a semi-arid/arid climate. Further, rainfall is also very limited, and hence it is expected that groundwater quality will remain same during different seasons. Thus, along with 

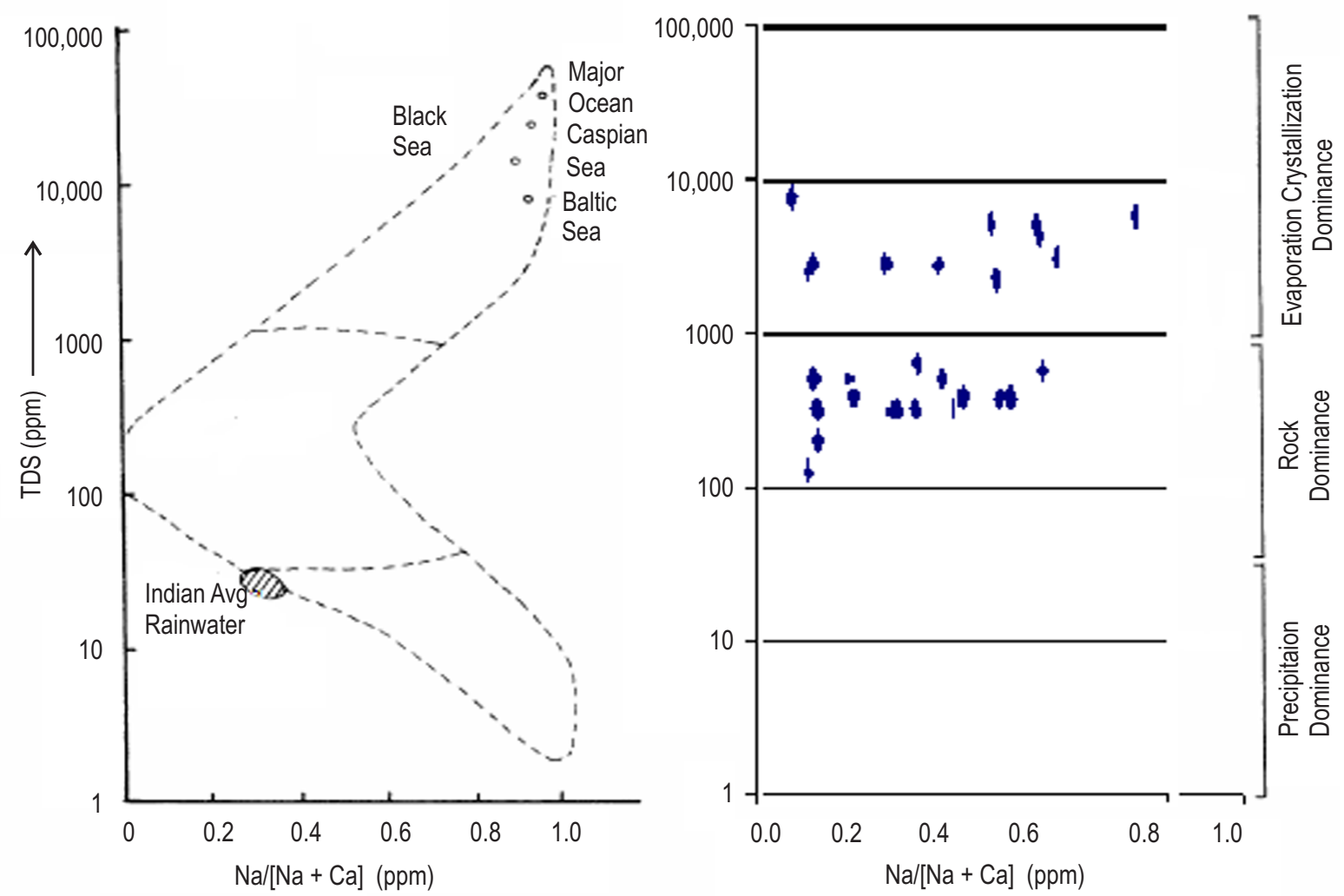

Fig. 5 : Gibb's plot showing hydro-geochemical processes in groundwater in Ellenabad.

anthropogenic activities, environmental conditions also play a major role to determine the water chemistry and quality of groundwater at a specific location.

Suitability of groundwater for use in irrigation can also be appraised based on various classifications i.e., based on TDS,
$\mathrm{SO}_{4}^{2-}, \mathrm{Cl}^{-}$and EC concentration (Table 4). The comparison of TDS or EC value of groundwater as shown in Table 4 reveals that majority of groundwater samples (17) can be categorized into excellent to good for irrigation and the remaining samples were found unfit for irrigation. The samples from these 11 locations

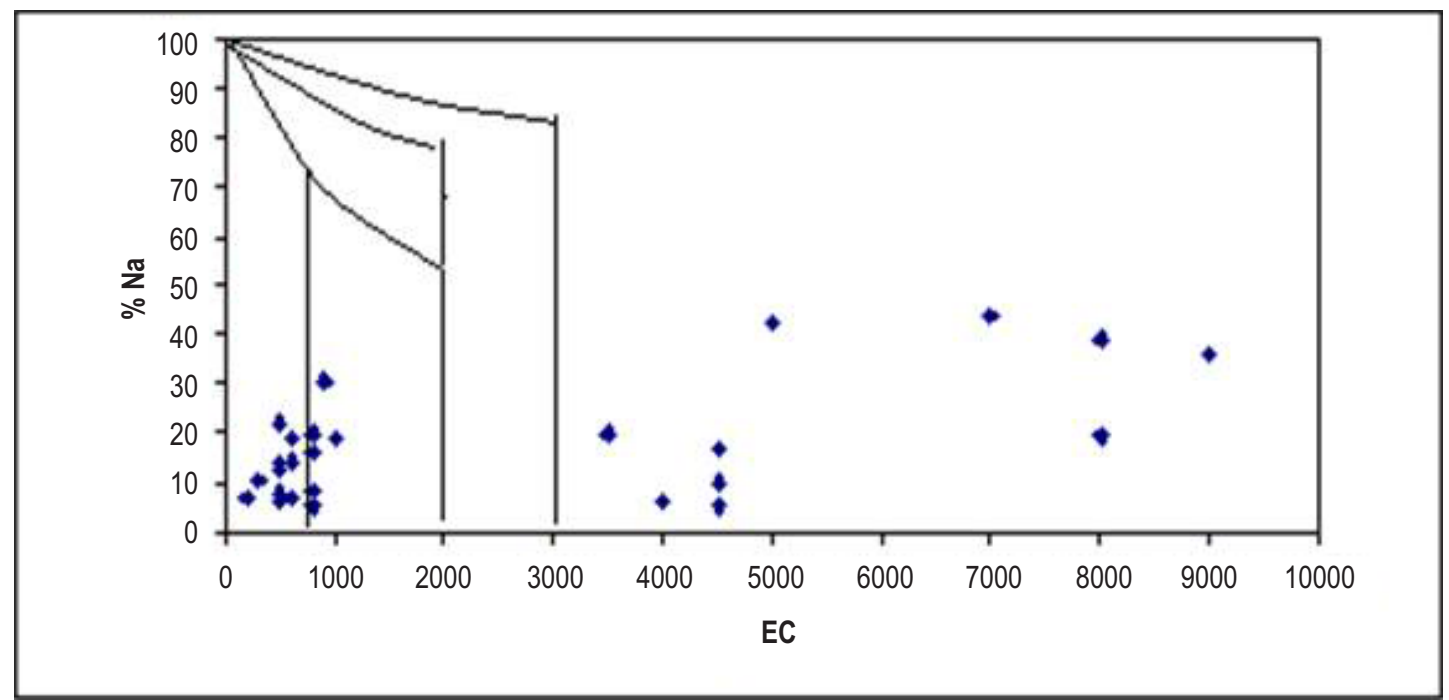

Fig. 6 : Suitability of groundwater for irrigation in the Wilcox diagram. 
Table 2: Comparison of groundwater quality parameters of Ellenabad with drinking water quality standards (BIS and WHO)

\begin{tabular}{llllll}
\hline Parameters & Concentration range & Mean \pm SD & & BIS Standards & WHO Limit \\
& & & Acceptable limit & Maximum limit & \\
\hline $\mathrm{pH}$ & $7.2-9.2$ & $7.8 \pm 0.4$ & $7.0-8.5$ & $6.5-9.2$ & $6.5-9.2$ \\
$\mathrm{EC}$ & $0.2-12.0$ & $2.9 \pm 3.3$ & - & - & - \\
$\mathrm{TDS}$ & $128-7680$ & $340 \pm 104$ & 300 & 1500 & 500 \\
$\mathrm{TA}$ & $268-1280$ & $521 \pm 263$ & 200 & 600 & - \\
$\mathrm{TH}$ & $17-1912$ & $415 \pm 860$ & 300 & 600 & 300 \\
$\mathrm{Na}^{+}$ & $5-111$ & $23 \pm 20.6$ & 50 & - & 200 \\
$\mathrm{~K}^{+}$ & $3-44$ & $12 \pm 9.2$ & - & 200 & 200 \\
$\mathrm{Ca}^{+2}$ & $11-482$ & $67 \pm 88$ & 75 & 100 & 105 \\
$\mathrm{Mg}^{+2}$ & $8-173$ & $62 \pm 41$ & 30 & 200 & 50 \\
$\mathrm{CO}_{3}^{2-}$ & $0.0-82$ & $25 \pm 23$ & 75 & - & 75 \\
$\mathrm{HCO}_{3}^{-}$ & $252-1218$ & $496 \pm 247$ & 30 & 1000 & 150 \\
$\mathrm{Cl}^{-}$ & $28-571$ & $223 \pm 171$ & 250 & 400 & 250 \\
$\mathrm{SO}_{4}^{2-}$ & $3-30$ & $16 \pm 7$ & 250 & 1.5 & 200 \\
$\mathrm{~F}^{-}$ & $0.01-0.9$ & $0.45 \pm 0.3$ & 1.0 & 0.5 \\
\hline
\end{tabular}

* Units of all the parameter are in $\mathrm{mg} \mathrm{l}^{-1}$ except $\mathrm{EC}(\mathrm{mS})$ and $\mathrm{pH}$

Table 3 : Suitability of groundwater for drinking purpose based on various classifications

\begin{tabular}{lcc}
\hline & \multicolumn{2}{c}{ Based on TDS concentration } \\
\hline Water class & TDS $\left(\mathrm{mg} \mathrm{l}^{-1}\right)$ & $\%$ of samples falling in each category \\
\hline Excellent & $<300$ & 7 \\
Good & $300-600$ & 50 \\
Fair & $600-900$ & 3 \\
Poor & $900-1200$ & 0 \\
Unacceptable & $>1200$ & 40 \\
\hline & Based on total hardness as $\mathrm{CaCO}_{3}\left(\mathrm{mg} \mathrm{l}^{-1}\right)$ after Sawyer and McCarty (1967) \\
\hline Soft & $<75$ & 7 \\
Moderately Hard & $75-150$ & 7 \\
Hard & $150-300$ & 32 \\
Very hard & $>300$ & 54 \\
\hline & Based on total hardness as CaCO $\left(\mathrm{mg} \mathrm{l}^{-1}\right)$ after Durfor and Becker (1964) \\
\hline Soft & $0-60$ & 4 \\
Moderate & $61-120$ & 10 \\
Hard & $121-180$ & 4 \\
Very hard & $>181$ & 82 \\
\hline & Nature of groundwater based on TDS (mg l-1) values \\
\hline Fresh & $0-1,000$ & 60 \\
Brackish & $1,001-10,000$ & 40 \\
Salty & $10,001-100,000$ & - \\
Brine & $>100,000$ & - \\
\hline & &
\end{tabular}

should not be used for irrigation as they may reduce the crop production. These finding are also supported by Fig. 6 , as most of the groundwater sample falls in 'very good to good' and 'good to permissible' class on the Wilcox diagram. Groundwater analysis based on $\mathrm{Cl}^{-}$content suggests that almost half of the samples were excellent for irrigation, however, eight samples fall in the range of good to injurious for crops. Remaining seven groundwater samples had $\mathrm{Cl}^{-}$concentration above $350 \mathrm{mg} \mathrm{l}^{-1}$, indicating unfit for irrigation. However, based on $\mathrm{SO}_{4}^{2-}$ content, all groundwater samples indicates that it was 'excellent to good' for irrigation.

Apart from the parameter discussed in Table 4, $\mathrm{Na}^{+}$is also a key element to assess groundwater quality for irrigation. Excess quantity of $\mathrm{Na}^{+}$can deteriorate the soil properties and may be 
Table 4 : Suitability of groundwater for irrigation based on various classifications

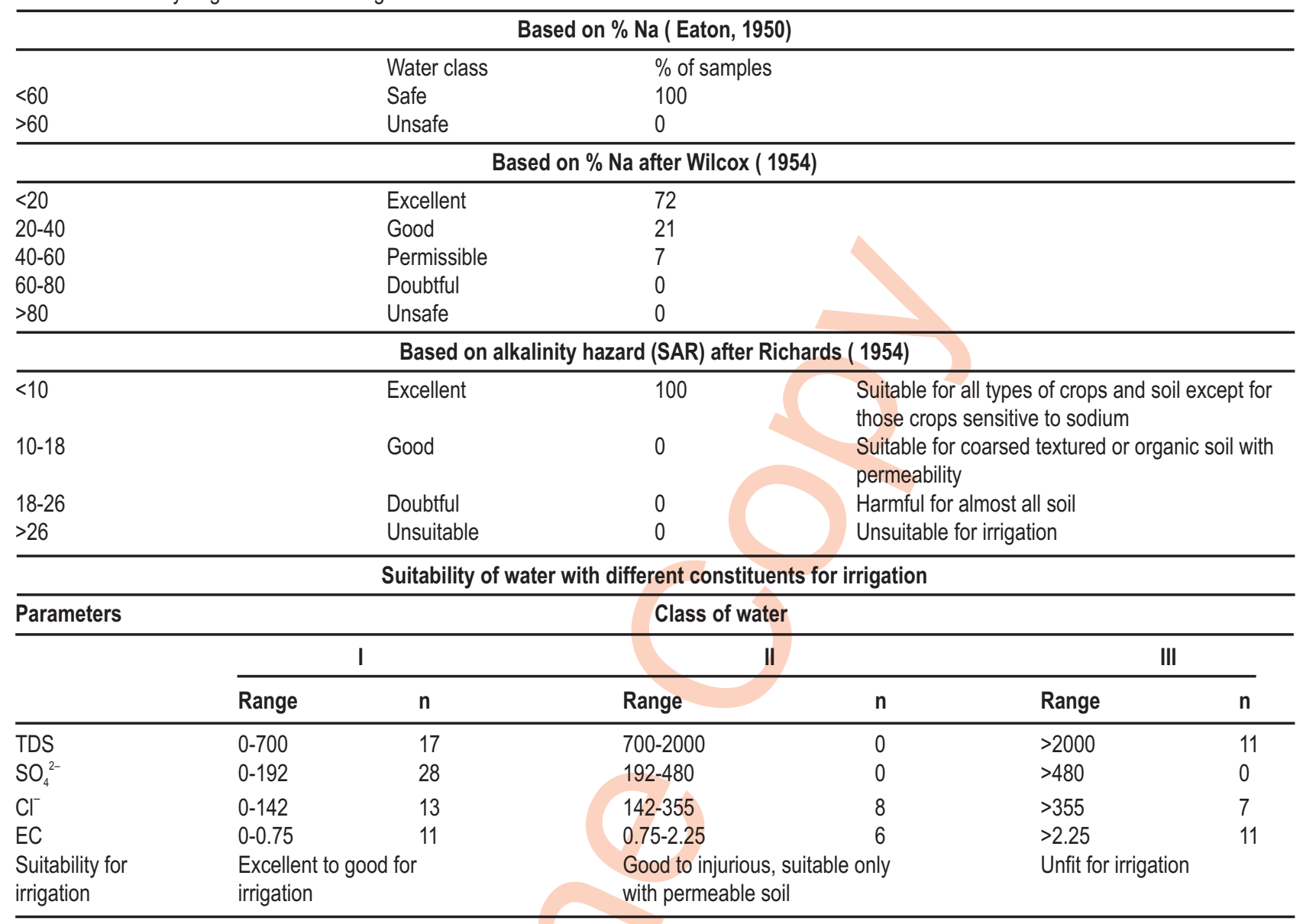

harmful to susceptible crops due to $\mathrm{Na}^{+}$phytotoxicity. As mentioned by Mor et al. (2009), $\mathrm{Na}^{+}$in groundwater can also be represented by Sodium Absorption Ratio, commonly known as SAR. Distribution of groundwater samples as per SAR categories is shown Table 4, which indicate that all groundwater samples were appropriate for the majority of crop species and soils. However, it is desired that soil organic matter should be high. Further, two groundwater samples may be harmful for soil except for soil having coarse texture with good permeability. Further groundwater samples from two sources should not be used for agricultural purposes. This study in agreement with Mor et al. (2009) which suggests that SAR should be estimated before water is utilized for irrigation purpose to protect sensitive crops from $\mathrm{Na}^{+}$phytotoxicity.

Correlation matrix was also generated to understand the relationship among the various groundwater quality parameters analyzed, which showed negative correlation of $\mathrm{pH}$ with $\left.\mathrm{K}^{+} \mathrm{B}=-0.480\right), \mathrm{Mg}^{2+}(\mathrm{r}=-0.424), \mathrm{Ca}^{2+}(\mathrm{r}=-0.413), \mathrm{TH}(\mathrm{r}=$ $-0.470), \mathrm{Cl}^{-}(r=-0.175)$ and TDS $(r=-0.126)$. However, Haritash et al. (2008) reported positive correlation of EC with TDS $(\mathrm{r}=0.822), \mathrm{Na}^{+}(0.782), \mathrm{Cl}^{-}(0.713)$, and $\mathrm{SO}_{4}{ }^{2-}(0.701)$ at 0.01 level of significance. Further, it could also be interpreted that salts of
$\mathrm{Ca}^{2+}, \mathrm{K}^{+}, \mathrm{Cl}^{-}$and $\mathrm{F}^{-}$contribute significantly to TDS. Besides, total alkalinity and $\mathrm{HCO}_{3}^{-}$was also found to be positively correlated with EC and TDS. A positive correlation was also observed between $\mathrm{TA}_{2} \mathrm{CO}_{3}^{-}, \mathrm{HCO}_{3}^{-}$and $\mathrm{Cl}^{-}$. TA also showed positive correlation with TDS $(r=0.595), \mathrm{CO}_{3}^{-}(r=0.699)$ and $\mathrm{HCO}_{3}^{-}$ $(r=0.998)$. Total alkalinity showed significant correlation with $\mathrm{HCO}_{3}^{-}(\mathrm{r}=0.998)$, which may help to maintain the buffering capacity of groundwater. Similar findings were reported by Bishnoi and Malik (2008) from Panipat, Haryana, where TA was found to be positively and significantly correlated with $\mathrm{HCO}_{3}$ $(r=0.992) \mathrm{K}^{+}$showed significant positive correlation with $\mathrm{EC}$ indicating its contribution towards EC. TH showed highly significant positive correlation with $\mathrm{Ca}^{2+}(\mathrm{r}=0.926), \mathrm{Mg}^{2+}(\mathrm{r}=0.884)$ and $\mathrm{K}^{+}(\mathrm{r}=0.599)$ and negative correlation with $\mathrm{CO}_{3}{ }^{-}(\mathrm{r}=0.563)$. $\mathrm{TH}$ also showed positive, highly significant correlation with $\mathrm{Ca}^{2+}$ $(r=0.926), \mathrm{Mg}^{2+}(r=0.884)$, indicating their contribution in building $\mathrm{TH}$ of groundwater. However, the degree of correlation of $\mathrm{Ca}^{2+}$ with $\mathrm{pH}$ was more which indicates the contribution of $\mathrm{Ca}^{2+}$ salts towards hardness than $\mathrm{Mg}^{2+}$. As most of the dissolved salts $\left(\mathrm{Ca}^{2+}, \mathrm{K}^{+}, \mathrm{Cl}^{-}\right.$and $\left.\mathrm{F}^{-}\right)$shows positive correlation with TDS, which can be used as a single indicator in routine water quality as a cost effective measure. 
Based on the current study and following the critical analysis of similar studies from Haryana, it could be inferred that groundwater of the region is very hard in nature. Hence, suitable preventive measures are required before it can be used for drinking purpose. Further, SAR of groundwater should be estimated before its use in agriculture to avoid damage to sensitive crops due to sodium phytotoxicity.

\section{Acknowledgments}

RK would like to thank Department of Health Research (DHR), Indian Council of Medical Research (ICMR), Ministry of Health and Family Welfare, for providing the Fellowship Training Programme in Environmental Health under Human Resource Development Health Research Scheme.

\section{References}

APHA: Standard Methods for Examination of Water and Wastewater. $21^{\text {st }}$ Edn., APHA, AWWA, WPCF, Washington DC, USA(2005).

Babiker, E.M. and F.A. Mohammed : Hydrochemical characteristics and water quality assessment of groundwater in Khor Adeit Area, North Eastern Sudan. J. Marine Sci. Environ. Tech., 1, E29-E42 (2015).

Babu, N. B., C. Gajendran, A.S. Hameed and E.J. James : Appraisal of groundwater quality for drinking and irrigation purposes in Nambiyar river basin, Tamil Nadu, India. Water Resources, 42, 553-562 (2015).

Bhat, M.A., M.S. Grewal, Ramprakash, Rajpaul, S.A. Wani and E.A. Dar: Assessment of groundwater quality for irrigation purposes using chemical indices. Indian J. Ecol., 43, 574-579 (2016).

Bureau of Indian Standards, BIS : Indian standard drinking water specification $\left(2^{\text {nd }} \mathrm{rev}\right)(2012)$. http://cgwb.gov.in/Documents/WQstandards.pdf

Chadha, D. K. : A proposed new diagram for geochemical classification of natural waters and interpretation of chemical data. Hydrogeol. J., 7,431-439 (1999).

Chitrakshi and A.K. Haritash : Hydrogeochemical characterization and suitability appraisal of groundwater around stone quarries in Mahendragarh, India. Environ. Earth Sci., 77, 252 (2018).

Durfor, C.N. and E. Becker: Public water supplies of the 100 largest cities in the United States. In: Geological Survey Water Supply. U.S. Government Printing Office, Washington, Paper No. 1812, p. 364 (1964).

Gibbs, R.J.: Mechanisms controlling world water chemistry. Science, 170, 1088-1090 (1970).

Garg, V. K., S. Suthar, S. Singh, A. Sheoran and S. Jain: Drinking water quality in villages of South Western Haryana, India: Assessing human health risks associated with hydrochemistry. Environ. Geology, 58, 1329-1340 (2009).

Garg, V. K., M. Amita, R. Kumar and R. Gupta : Basic dye (methylene blue) removal from simulated wastewater by adsorption using Indian Rosewood sawdust: A timber industry waste. Dyes and pigments, 6, 243-250 (2004)

Gupta, R. and A.K. Misra: Groundwater quality analysis of quaternary aquifers in Jhajjar District, Haryana, India: Focus on groundwater fluoride and health implications. Alexandria Engin. J., 57, 375-381 (2016).

Gupta, R. and A.K. Misra: Drinking water quality problem in Haryana, India: Prediction of human health risks, economic burden and assessment of possible intervention options. Environ. Develop. Sustain., pp.1-15(2018).
Haritash, A. K., C.P. Kaushik, A. Kaushik, A. Kansal and A.K. Yadav : Suitability assessment of groundwater for drinking, irrigation and industrial use in some North Indian villages. Environ. Monitor. Assess., 145, 397-406 (2008)

Haritash, A.K., A. Aggarwal, J. Soni, K. Sharma, M. Sapra and B. Singh: Assessment of fluoride in groundwater and urine and prevalence of fluorosis among school children in Haryana, India. Appli. Water Sci., 8, 52 (2018).

Jalali, M.: Assessment of the chemical components of Famenin groundwater, Western Iran. Environ. Geochem. HIth., 29, 357-374 (2007).

Jebreen, H., S. Wohnlich, A. Banning, F. Wisotzky, A. Niedermayr and M. Ghanem: Recharge, geochemical processes and water quality in karst aquifers: Central West Bank, Palestine. Environ. Earth Sci., 77, 261 (2018).

Kaushik, A., K. Kumar, Kanchan and H.R. Sharma : Water quality index and suitability assessment of urban groundwater of Hisar and Panipat in Haryana. J. Enviorn. Biol., 23, 325-333 (2002).

Kulkarni, H., M. Shah and P.V. Shankar: Shaping the contours of groundwater governance in India. J. Hydrology: Regional Studies, 4, 172-192 (2015).

Kulshrestha, $\mathrm{H}$. and $\mathrm{S}$. Sharma: Impact of mass bathing during Ardhkumbh on water quality status of river Ganga. J. Environ. Biol., 37, 437-440 (2006).

Kumar, S., P. Rani and H.R. Sharma: Changing patterns of ground water level in Fatehabad district of Haryana, India. J. Environ. Earth Sci., 6, 95-98 (2016).

Kumar, M.,A. L. Ramanathan, M.S. Rao and B. Kumar : Identification and evaluation of hydrogeochemical processes in the groundwater environment of Delhi, India. Environ. Geology, 50, 1025-1039 (2006).

Madhavi, A. and A.P. Rao: Effect of industrial effluent on properties of groundwater. J. Environ. Biol., 24, 187-192 (2003).

Mor, S., K. Ravindra, R.P. Dahiya and A. Chandra : Leachate characterization and assessment of groundwater pollution near municipal solid waste landfill site. Environ. Monitor. Assess., 118, 435-456 (2006).

Mor, S., S. Singh, P. Yadav, V. Rani, P. Rani, M. Sheoran and K. Ravindra: Appraisal of salinity and fluoride in a semi-arid region of India using statistical and multivariate techniques. Environ. Geochem. Hlth., 31, 643-655 (2009).

Mor, S., K. Kaur and R. Khaiwal : SWOT analysis of waste management practices in Chandigarh, India and prospects for sustainable cities. J. Environ. Biol., 37, 327-332 (2016).

Mor, S., K. Kaur and R. Khaiwal: Growth behavior studies of bread wheat plant exposed to municipal landfill leachate. J. Environ. Biol., 34, 1083-1087 (2013)

Mukarukunda, J., K. Sanjay, P. Raj, P. Ram and S.K. Sharma: Assessment of groundwater quality of Ellenabad block of Sirsa district, Haryana. Annals of Biology, 32, 219-223 (2016).

Negi, P., S. Mor and K. Ravindra: Impact of landfill leachate on the groundwater quality in three cities of North India and health risk assessment. Environ. Develop. Sustain., (2018). DOI: 10.1007/ s10668-018-0257-1.

Ravindra, K. and A. Kaushik: Seasonal variations in physico-chemical characteristics of River Yamuna in Haryana and its ecological bestdesignated use. J. Enviro. Moni., 5, 419-426 (2003).

Ravindra, K. and V.K. Garg : Distribution of fluoride in groundwater and its suitability assessment for drinking purpose. Int. J. Environ. Health Resea., 16, 163-166 (2006).

Ravindra, K. and V.K. Garg : Hydro-chemical survey of groundwater of Hisar city and assessment of defluoridation methods used in India. Environ. Monitor. Assess., 132, 33-43 (2007). 
Rao, N. S., P.S. Rao, G.V. Reddy, M. Nagamani, G. Vidyasagar and N.L.V.V. Satyanarayana: Chemical characteristics of groundwater and assessment of groundwater quality in Varaha river basin, Visakhapatnam district, Andhra Pradesh, India. Environ. Monitor. Assess., 184, 5189-5214 (2012).

Richard, L.A. : Diagnosis and improvement of saline and alkaline soils. In: Agricultural Hand Book, 60. USDA, Washington, DC, p. 160 (1954)

Sawyer, C.N. and P.L. McCarty : Chemistry for Sanitary Engineers. $2^{\text {nd }}$ Edn., McGraw-Hill New York (1967).

Shankar, K., S. Aravindan and S. Rajendran: Assessment of groundwater quality in Paranavar river sub-basin, Cuddalore district, Tamil Nadu, India. Adv. Appli. Sci. Res., 2, 92-103 (2011).

Sharma, H.R., W. Worku, M. Hassen, Y. Tadesse, M. Zewdu, D. Kibret, A. Gashe, M. Meseret, D. Gessesse and A. Kebede : Water handling practices and level of contamination between source and point-ofuse in Kolladiba Town, Ethiopia. Environ. We Int. J. Sci. Technol., 8 25-35 (2013).

Sharma, H.R, B. Destaw, T. Negash, L. Negussie, Y. Endris, G. Meserte, $B$. Fentaw and $A$. Ibrahime : Municipal solid waste management in Dessie City, Ethiopia. Manag. Environ. Quality: An Int. J., 24, 154 $164(2013)$

Sheikh, M. A., C. Azad, S. Mukherjee and K. Rina : An assessment of groundwater salinization in Haryana state in India using hydrochemical tools in association with GIS. Environ. Earth Sci., 76, 465 (2017).

Singh, B. and V.K. Garg : Fluoride quantification in groundwater of rural habitations of Faridabad, Haryana, India. Int. J. Environ. Protection, 2, 8-17 (2012).

Singh, R., R.K. Jhorar, van J.C. Dam and R.A. Feddes : Distributed ecohydrological modelling to evaluate irrigation system performance in Sirsa district, India II: Impact of viable water management scenarios. J. Hydrology, 329, 714-723 (2006a).

Singh, R., J.G. Kroes, van J.C. Dam and R.A. Feddes : Distributed ecohydrological modelling to evaluate the performance of irrigation system in Sirsa district, India: I Current water management and its productivity. J. Hydrology, 329, 692-713 (2006b).

Thapliyal, A., P. Vasudevan, M.G. Dastidar, M. Tandon and S. Mishra: Irrigation with domestic wastewater: Responses on growth and yield of ladyfinger Abelmoschus esculentus and on soil nutrients. J. Environ. Biol., 32, 645651 (2011)

United Nation Sustainable Development Goal, (2015). http:// www.un. org/ga/search/view_doc.asp?symbol=A/RES/70/1\&Lang=E

World Health Organization (WHO) : Guidelines for drinking-water quality. $3^{\text {rd }}$ Edn.,. $1^{\text {st }}$ Addendum to 1. WHO Press (2006).

Yadav, P., B. Singh, S. Mor and V.K. Garg : Quantification and health risk assessment due to heavy metals in potable water to the population living in the vicinity of a proposed nuclear power project site in Haryana, India. Desalination and Water Treatment, 52,7586-7597(2014).

Yadav, J. P., S. Lata, S. K. Kataria and S. Kumar : Fluoride distribution in groundwater and survey of dental fluorosis among school children in the villages of the Jhajjar district of Haryana, India. Environ. Geochemi. Hlth., 31, 431-438 (2009). 